\title{
REPUBLICAN GOVERNMENT IN CHINA
}

\author{
By Chester Lloyd Jones, \\ Associate Professor of Political Science, University of Wisconsin.
}

For a quarter of a century political prophets have been foretelling the awakening of China. Each year seemed to promise the abandonment of the old and the entry of the new regime, but each year at its end left conditions surprisingly like they were at its beginning. So often were we told of the dawn of a new day for China and so often disappointed that many despaired that the sleeping giant would ever awake, and the countries of Continental Europe even concluded that his goods were for him who would take them.

\section{Plans to Adopt Experience of Western Nations}

The last ten years have shown, not a foreign policy increasingly strong but a realization on the part of China of her own weakness. She has recognized the necessity of an entire recasting of her form of government. The Boxer troubles and the subsequent settlement with foreign powers brought home even to the conservative Manchu throne the necessity of at least a conservative program of reform. In 1906 the first traveling commission of five members was appointed to discover by study in Europe and America the reasons for the national strength of Western States. China had ceased to look upon her own civilization as perfect, and was willing to adopt whatever had proved excellent in the experience of others. The returning commission reported, "It is the unanimous opinion of these commissioners that the backward condition of China is due in the main to the lack of confidence between the throne and the ministry, on the one hand, and the masses of the people on the other." On February 18, 1907, an imperial decree issued declaring: "Foreign countries acquire wealth and power by granting constitutions to their people with the privilege of the ballot. Thus the interests of the Sovereign and his people are interlaced so that what affects the one affects the other. It is necessary that we in China should, after careful investigation, prepare to imitate this constitutional type of government, and, while retain- 
ing supreme control in the hands of the Throne, should entrust the administration of their own interests to the people themselves, through their chosen representatives."

But this could not be done at once. A preparatory program was outlined. The official system was to be reformed, the laws were to be revised, universal education established, the army was to be reorganized, an efficient system of police introduced, and the revenue and expenditures of the government placed on a sound basis. This was no small program in itself, a series of tasks which would stagger the boldest of administrators even in a country with a government as absolute as that of China is in theory, but is not in fact.

\section{Provincial Experiments}

In one province the policy of reform was immediately put to the test. In Chih-li, the most important viceroyalty of the empire, one of the ablest of Chinese statesmen, Yuan Shih-kai, was viceroy. He at once introduced important reforms throughout the province, especially at its principal city, Tientsin. Public works and police were put in a state of efficiency previously unknown. The provincial officials were given periodical instruction in constitutional government, at the provincial capitol. To prepare the people for their coming responsibilities, the first step the Viceroy concluded would be to introduce local self-government.

A beginning was made in 1907 when the first "popular" municipal government in China was set up in Tientsin. The government was organized on western models adapted to local needs. A municipal council of thirty members was elected for two years by a convention of $\mathrm{I} 35$ delegates chosen at a general election. This indirect election is not different in principle from the way in which Senators are elected in the United States.

The suffrage is restricted. Only males, twenty-five years of age or over, able to read and write, natives of the city or five-year residents, owning property to the value of 2,000 taels can vote. A candidate must be a qualified voter who is a college graduate or author of a work which has received official recognition, or a director of a school or public enterprise, or an ex-official. The voting methods follow the best western usage, and the proceedings of the council are protected nominally at least by the usual parlia- 
mentary privileges. An executive board of nine, elected for four years, part of whom retire every two years, carries out the decrees of the council. The first election under the new regime was held on June I5, I907, and the electoral college met on July 24, to select the Municipal Council of Tientsin. The latter body convened August I8th.

The experiment was one avowedly undertaken to test the possibility of introducing western forms of government into China. If successful the system was to be extended to other provinces so that training in self-government might precede the introduction of the national constitution. Each province was to be granted a provincial constitution and to conduct its affairs through a representative assembly, which was to serve de facto as a training school for the new national legislature. The success of the first experiment encouraged starting further reforms. September I, 1907, an edict issued promising a constitutional government as soon as the people were ready for it. The people were promised a new national legislature to consist of two houses. A preliminary step was taken at once in the calling of a national consultative assembly known as the "Council of Advice." Its members are nominated partly by the central government, partly by the provincial assemblies. The functions of the body are indefinite, but are probably intended to be advisory rather than truly legislative, like the advisory councils of India.

Another edict established similar consultative assemblies in the provinces to discuss projects of provincial legislation. From these assemblies a certain portion of the members of the national body were to be selected. The provincial assemblies it was first planned to have chosen by the governors, but the protests which arose brought the issuance of a new edict in 1908 by which they were made elective. This does not mean, however, a true popular election; for in the provincial elections as in the municipal election at Tientsin a property qualification is enforced which, quite apart from other requirements, shuts out all but a small portion of the people.

\section{The Proposed National Legislature}

Public opinion now began to outrun the government's plans for reform. As mentioned above, the government had to make concessions in the manner of election to the provincial assemblies. 
It was also objected that the decrees were not definite as to the powers and organization of the proposed national legislature. The nomination of a portion, presumably the majority, of the members, especially aroused criticism, because the people considered it an expedient by which the form of power was granted though the substance was withheld. The principle of election recognized in the provincial assemblies they felt should be extended to the national body and its powers should be made truly legislative. National regeneration could be brought only by the speedy creation of a sovereign parliament based on direct election by the people of the provinces. Universal suffrage they still recognized would be unwise. Property or educational qualifications would be accepted, but the representative principle must be recognized.

Feeling its hold on popular opinion slipping away, the government in December, 1907, issued decrees urging conservatism and asking that the people in their enthusiasm for western methods of government should organize in the orderly manner adopted by European political parties. Partly due to the pressure of public opinion, too, there had been created in 1907 a "Commission for the Study of Constitutional Government," to make a study of the political conditions and needs of China, and make a report to the throne and Grand Council as to what foreign political institutions should be adopted or adapted to Chinese needs. The commission set to work at once. A vote taken in May, I908, is significant of the temper of its members. On the question of how soon a constitution should be granted, four voted for a delay of two years, seven for five years, eight for seven years, twelve for ten years, and one for twenty years. Those who voted for the shorter periods had been educated in the old Chinese classic schools or in Japan, those favoring a longer delay in America or Europe. The government still stood with the conservatives, and on August 28, declared again for the issuance of a constitution in I9I7.

The Commission for the Study of Constitutional Government outlined a plan of reform which was to extend over the intervening period and would prepare the public for its new responsibilities. Prominent among the projects was the introduction of new educational methods by which the commission hoped that one-half of the population of China would be able to read and write at the time the constitution was actually granted. 


\section{The Work of the Provincial Legislatures}

Meanwhile the plans for elective provincial assemblies were being rapidly forwarded. The first provincial elections occurred in the spring of I909. On October I4, provincial assemblies met in every province of China to discuss the affairs of the respective provinces. They met again in I9IO, surer of their powers and enthusiastic for local reforms. In several of the provinces they came into active conflict with the policies of the local governors. Differences of this sort were carried to the central government, which is said to have given its moral support uniformly to the local legislatures against the governors.

Constructive legislative work also seems to have been accomplished in most of the provinces. The success attending the suppression of opium in Szechwan, the most populous province of all China, is largely due to the action of the local legislature, and in Kwantung, the great southern province, gambling has been successfully repressed by the same means. It is the generally expressed belief that the provincial assemblies give promise of fully justifying their creation.

An interesting outgrowth of the provincial bodies is the "United Association of the Provincial Assemblies," formed in Pekin in June of this year, which has committed itself to the program "To respect the monarch and constitution, to improve and reform administrative matters in the provinces, to develop the financial resources of and for the people, to further popular intercourse with foreigners and exalt the military spirit in education."

\section{The National Assembly}

The second year of the local assemblies was the one in which occurred the first meeting of a national representative body in China. On October 3, I9I0, the Prince Regent opened a meeting of an assembly of 202 members, the majority appointed by the government, the others elected by the provincial assemblies. Here, as in the Commission for the Study of Constitutional Government, the question of the date for issuing the new constitution forced itself into consideration. The conservatives again urged a period of delay for preparation, but public opinion had rapidly grown in favor of creating a national legislature of two houses as soon as possible. 
It was strongly urged that every year of delay which left China without an efficient government increased the influence of foreigners in the Far East, accentuated the desire for exclusive trade privileges and threatened Chinese independence. Partly because of this fear of foreign influence and partly because public opinion would not be satisfied without concessions, the government yielded and fixed the summoning of a national parliament of two houses for I9I3. Demands were made for a responsible cabinet, and the discussion of the national budget took much of the time of the assembly.

The most significant features of the first assembly were its moderation and its insistence that when the constitution is granted it shall include a grant of real responsible government. The expressions both within and outside of the national assembly were decidedly to the effect that the people would not be satisfied without the recognition of the elective principle and a responsible cabinet. To forward these ends there have already arisen political societies known as the Association for Study of the Constitution, and the Association for Preparing Constitutional Citizenship.

On October 22, I9I I, at Pekin, began the second session of the National Assembly. In the face of the rapidly spreading revolution it is not to be wondered at that it adopted an anti-dynastic and radical program. On the twenty-fifth, it denounced the policy of the government, and the following day memorialized the throne for the immediate institution of a popular parliament. Among its other demands were several for constitutional changes. Parliament is to have full power to revise the constitution. A responsible cabinet is to be formed with a premier chosen by parliament. The parliament is to share the treaty making power and control taxation and the budget. No appointive members are to have a place in the upper house of parliament until the reforms are completed. Under this pressure the government yielded, a constitution was drawn up embodying the reforms, which the crown is declared ready to accept.

\section{The Revolutionary Program}

During the year the revolution had spread so rapidly that these radical concessions were no longer acceptable, and opposition to the throne continued. On November 15 , one of the most influential revolutionary leaders, Wu Ting-fang, former minister to the 
United States, issued a proclamation to the world in which recognition for the Republic of China was asked. It represented the ideals of the more extreme Chinese reformers. It read in part: "Already we have provincial assemblies and a national assembly. Already we have a republic with a full set of competent officials. Within a few days the Constitutional Convention will meet. . . . A constitution of the most enlightened character will be adopted. Following will come . . . provincial national elections. Out of the chaos and dust of the falling throne emerges a free enlightened people, a great natural democracy of 400,000,000 human beings. They have chosen to set up a republic. . . . This is a great democracy." The words of the proclamation, like our own declaration of independence, are not to be taken literally. They represent a declaration of ideals rather than a program of action.

Outside of the empire the plans of the extreme reformers have been viewed with misgivings. The introduction of representative institutions resting on a broad popular basis which threatens to become a part of the reform program is a project which conservative opinion holds may be productive of worse disorder and inefficiency than that which is to be overcome. It is hoped that the influential middle class and the natural conservatism of the Chinese may save them from an advance which may by too rapid a break with previous customs and conditions bring a reaction as unfortunate as that which marked the closing years of the nineteenth century.

\section{Republican Government Impracticable}

Parliamentary institutions may be introduced in China, they have shown themselves adaptable to widely varying civilizations, but there are several reasons why a republican government in the sense in which that term is understood in America must still be something which for China will be an ambition rather than a reality.

The most important limitation on the possibility of a republican China is physical. We no longer believe that republics must be confined to small area and limited territory. The invention of the representative system made large republics possible even before the invention of the steam engine and the telegraph. But it still holds true that the difficulties of popular government increase in almost 
geometric ratio when area and population become larger without a proportionate increase in ease of communication. We may well doubt whether republican government would be as great a success in the United States as it now is if our railroads, telegraphs and telephones should drop out of existence. Our local officers could still be elected for it is still possible for the candidate to reach them by word of mouth, but a national campaign with our present development in population and territory would be almost an impossibility. How much greater would be the difficulty of carrying on a campaign before a truly popular electorate in China in the face of the transportation conditions found there is shown by a comparison of land areas and population.

The total land area of China proper is $1,532,420$ English square miles, that of Continental United States is 1,175,742 English square miles. Communication in the United States by telegraph and steam makes the country practically a unit so far as the transmission of intelligence is concerned. China has hardly begun on her railway and telegraphic development. The Chinese Imperial Customs estimated the population of China proper in 1906 at $438,000,000$ souls, the population of the United States in 1910 was 91,972,266. Even assuming all other conditions to be equal the organization of any true republican government in China, under such conditions, would be a task which only a republican enthusiast such as William $\mathrm{H}$. Seward would consider easy. But the actual conditions make the task a hundred fold more difficult. A population five times as great as that of the United States living under transportation conditions not even so good as obtained with us in the days of the canal and stage coach cannot conceivably be reached by party organization. The party machine operating under such disadvantages would break with its own weight. There could be no intelligent expression of public opinion. Not only in politicalaffairs, but in every other field, it is impossible to develop an alert, quickly changing public opinion in a nation of over four hundred millions when mediaeval means of communication are supplemented only by a few thousand miles of railroad and telegraph. China cannot become a popular republic without an improved system of communication.

A second difficulty which confronts republican government in China is the lack of general education and the imperfect character of that which does exist. The people of China as a whole are not 
educated for self-government. The grinding necessities of everyday life have shut them off from the possibility of intellectual development. Further, even the educated Chinese have no political training or experience. The old Chinese classic education, divorced from the affairs of everyday life and essentially unpolitical in character, was swept away by Imperial Edict of September 3, 1905, only seven years ago. Since that time great enthusiasm for "western learning" has overspread large sections of the empire. Large numbers of schools have sprung up to supply the demand, but the new instruction is still a reflection from foreign lands rather than a part of the national life, and even such as it is it has not touched the mass of those who in a popular government would be called upon to bear public burdens and determine public policy. China cannot become a popularly governed nation until her educational system has been modernized and brought within reach of the great mass of the population. This is not a problem of a decade, but of at least a generation. In any nation such as China the reorganization of instruction on modern lines means a great increase of national expenditure, an increase which China cannot now nor in the near future assume.

This brings us to the third limitation on the use of popular government in China-the poverty of the country. We are apt to think of China as a land of tea and silks in which the luxury which we associate with the word "Oriental" is a characteristic of the civilization, but the facts make the orient a synonym for poverty rather than riches.

Popular governments are expensive governments. Even if popular government in China would remove the official "squeeze", and the experience of other countries does not show that that result would be automatic, it is doubtful whether the people could bear the expense of biennial or even quadrennial popular elections. If the expense of a national election in the United States with ninety million people runs as high as sixteen million dollars, what would be the expense of an election covering four hundred millions with the added disadvantage of poor communications? It seems hard to avoid the conclusion that in a country so poor as China popular elections would not have popular support, and would even more surely fall into the hands of those who could profit by position, than is the case in western nations. China cannot hope for republican 
government on a popular basis until her tremendous economic resources are unlocked in such a way that the standard of life of the average man will rise appreciably above the minimum of subsistence.

Finally admit that communication may be improved, that education may be brought within the reach of the average man, that the average citizen may be raised to an economic position of passable independence, and there still remains the difficulty of the enormous size of the electorate. This is not an insurmountable obstacle, the population of the United States is larger by half than the largest province of China, but a population over four times that of the United States and much over twice that of the two Americas is not easy to organize into political parties even if the unpolitical Chinese develop into the most politically-active nation of the world. The federal form of government might be adopted, but even this would leave the national elections a serious problem, and the organization of the provincial electorates would be no small matter.

The single province of Szechwan had a population in 1906 of $68,724,890$, more than twice as large as that of the United States at the time of the civil war and almost six times as great as New York State in IgIo. An election of Governor in Szechwan would involve a population half as large again as that now living in New England, the old northwest territory, New York, New Jersey and Pennsylvania. The average provincial election would be held in a territory containing three times as many people as Pennsylvania. The enormous cost of organizing such an electorate we may judge from our own much less extensive task. The chance for corrupt methods among those unused to political responsibility and living on a low standard of life can be left to conjecture.

\section{Prerequisites for Republican Government}

If China is ever to become a popular republic on western lines, that day is not near. Economic transformation must come before more than the form of popular government is possible. Revolutions may come and change the organization of the government, an elected president may take the place of the long lived Manchu dynasty, and political developments of this limited sort may help change the economic conditions which make more radical political 
changes now impossible. But a republic as that term is understood in America, a government which is controlled through the suffrages of the people or of a considerable share of them, is still far off. China may have a government for the people, but not now one by and of the people. Popular government will come to China as it has come to the rest of the world, only through a slow change of custom and conditions and through a long period of national travail.

For a popular form of government the people must attain a measure of intelligence and a degree of economic independence. To create them, it is first essential that the economic resources of China should be unlocked. For this in turn enormous amounts of capital are necessary. China cannot lift herself by her bootstraps. She has no supply of domestic capital adequate to her needs so she must borrow, and borrow heavily. This was the experience of the United States. To create the possibility of borrowing on any terms which would not threaten the future of the country, the first essential is a strong government which shall inspire confidence on the part of foreign capital and make possible the contracting of both public and private loans on conditions which will assure the greatest benefit to China. When China has solved her economic problem, possibly while she is solving her economic problem, the question of better education for the population can be solved and a greater degree of popular control may be introduced. But for the present her first need is a strong government, and under present conditions that means a government by the few.

The sober thought of China does not overlook the country's limitations. It seems highly unlikely whatever success attends the revolution that there will be a hasty attempt to create in the Far East a New West. Many of the glowing accounts by representatives of young China which have found their way into American newspapers before and since the beginning of the revolution would have been more conservatively phrased had there been probability of putting the plans into action.

If republican institutions are to be introduced into China, it will be slowly and at first only in a very limited form. Whether an elective executive replace the monarch is not of prime importance. It has become familiar to us that the form of the executive is not an essential test of the existence of government by the people. 


\section{Lesson of European Experience}

Out of the present turmoil some form of parliamentary government will be evolved. The general lines on which the government will develop can to some extent be estimated. To rule China with a system of prefectures such as are found in civilized France, would not only be to use a system under which it would be hard to adjust the law to varying provincial needs, but would run counter to the traditions of the Chinese. Government does not bulk large in Chinese life. The detailed regulation to which we in western countries are accustomed is absent. The government taxes, it controls appointments and examinations for office. Farther than this there have been only occasional assertions of authority. Local self-government is left to work itself out almost without interference. Whatever the theory of the government, the average Chinese is still an ardent advocate of laissez faire.

The introduction of parliamentary government in China involves therefore a balance of local autonomy and a strong government. The organization will almost certainly be federal in fact, even if a semblance of the present theoretical centralization be preserved. Since the central government has occupied in the past so restricted a field, how to secure for it the power it should have under the new conditions will be a difficult problem. It seems that whatever form Chinese parliamentary institutions may assume they will more closely resemble those of the more conservative European federative governments than those of the United States.

Germany and Austria, perhaps even Russia, seem likely to be the countries whose experience will offer institutions most easily adapted to Chinese conditions. The constitution of the former country has been given lavish praise by Chinese scholars. The preferences already shown by the Chinese in both provincial and municipal reforms indicate the popularity of the principle of indirect election, examples of which are found in the Prussian and Austrian electoral laws. The method of selection of the Central Parliament in Austria-Hungary, through co-option of a number of members from the local parliaments, is an expedient by which a national body is secured without a national organization of the electorate with its attendant expense, and the disadvantage of enforcing uniformity where diversity is needed. The right of wealth to be represented even to the exclusion of numbers is a rule of prac- 
tice in the Chinese municipal elections so far set up. Even if the popular demands bring a wider suffrage the predominance of the well-to-do may be preserved by the adoption of the Prussian three class systenn of voting assuring to those who have the greatest economic stake in the community, the control over its government. Partly prompted by similar reasons many Chinese scholars have urged the adoption of a scheme of representation of interests such as has been used in Russia and Austria-Hungary. Spiritual interests, boards of trade, representatives of great landed estates, municipalities, universities and rural communes have in the practice of these countries been given a legal share in governmental control. The legislature has become representative of the institutional life of the state rather than of its individual members. Such a plan fits in well with Chinese conditions, the extra-legal guild organizations would if granted representation under such a system prove a valuable support to the government. As has been found in Russia, this method of organization of the state gives great flexibility for the representation of the most diverse sorts of interests and a large variety of governmental units having quite as little in common as Manchuria and Yunnan.

In summary, China will probably find the experience of the countries of Eastern Europe suggestive of what may well be done in the Far East. For this there are many reasons; in the countries of Eastern Europe

(I) Federal relations are well elaborated.

(2) A large degree of local autonomy is kept.

(3) Local customs and preferences are respected.

(4) Wealth receives consideration in representation.

(5) The popular element is introduced into government,-distantly it is true, but perhaps as much as Chinese conditions render safe; and

(6) All this is done while the central administration is left in a commanding position.

The Chinese have suffered too long from inaction. It can hardly be wondered if they desire now to turn to strong government to rescue them from the failures of a government strong only in theory. 